\title{
HYGIENIC ASSESSMENT OF THE STATE OF WASTE MANAGEMENT IN THE RIVHE REGION IN 2012-2018
}

\author{
Stankevych V.V., Brezytska D.M., Hushchuk I.V., Hilman A.Y., Kulesha N.P.,
} Safonov R.V., Horonzhevska I.S.

\section{ГІГІЕНЧЧНА ОЦПНКА СТАНУ ПОВОДЖЕННЯ З ВІДХОДАМИ У РІВНЕНСЬКІЙ ОБЛАСТІ У $2012-2018$ РОКАК}

нтенсивне забруднення довкілля створює реальні загрози для біологічного різноманіття нашої планети. Ключовими забруднювачами ґрунту, поверхневих і підземних вод, харчових продуктів та атмосферного повітря $€$ відходи, які можна класифікувати за походженням і за властивостями [1-3]. Однією з найактуальніших екологічних проблем для України є проблема поводження з відходами. За даними Держстату України, загальний обсяг накопичених відходів становить 12,5 млрд. т [4].

За неофіційними даними, в Україні накопичено близько 40 млрд. т відходів, з яких 5 млрд. т належать до категорії небезпечних. Нині з 35 тисяч сміттєзвалищ лише трохи більше 6 тисяч - паспортизовані об'єкти. Орієнтовно площа усіх сміттєзвалищ становить 7\% території України, тобто більше, ніж площа природнозаповідного фонду (близько 6\%).

Україна $€$ лідером в Європі 3 забруднення своєї території. За різними оцінками, щорічні обсяги утворення відходів в Україні становлять 400-500 млн. т (без урахування тимчасово окупованих територій, Автономної Республіки Крим), а обсяги накопичення відходів сягають 25 тис. т на квадратний кілометр.

За різними оцінками, обсяги утворення твердих побутових відходів (ТПВ) в Україні становлять понад 11 млн. т, дуже мало використовується вторинна сировина із ТПВ. Відсортовується та утилізується лише 5,6\%.

Найбільше промислових відходів утворюють гірничо-видобувний комплекс та теплоенергетики (вскришні породи, хвостосховища, золошлакові відвали тощо). Їхні відходи належать до 4-го класу небезпеки - безпечні відходи. Проте, враховуючи їхні фізико-хімічні властивості (дрібнодисперсну складову з високою здатністю до утворення пилу в атмосферному повітрі), вони належать до II класу небезпеки високонебезпечні та III класу помірно небезпечні відходи [5, 6]. Окрему групу небезпечних відходів становлять не придатні
ГІГІЄНІЧНА ОЦІНКА СТАНУ ПОВОДЖЕННЯ З ВІДХОДАМИ У РІВНЕНСЬКІЙ ОБЛАСТІ У 2012-2018 РОКАХ

1 Станкевич В.В., 2 Брезицька Д.М., 2Гущук І.В., 2ільман А.Ю., 2 Кулеша Н.П., ${ }^{3}$ Сафонов Р.В., ${ }^{3}$ Хоронжевська І.С. 1 ДУ «Інститут громадського здоров'я ім. О.М. Марзєєва НАМН України», м. Київ 2 Науково-дослідний центр екології людини та охорони громадського здоров'я

Національного університету «Острозька академія», м. Острог, Україна

ЗДУ «Рівненський обласний лабораторний центр МОЗ України», м. Рівне, Україна

Мета. Гігієнічна оцінка стану поводження 3 відходами у Рівненській області у 2012-2018 роках.

Методи. Систематизація, обробка та аналіз матеріалів досліджень проводилися за допомогою описового, динамічного та порівняльного методів.

Результати. Аналіз даних щодо кількості утворених відходів за 2012-2018 роки показав, що 2013 року кількість утворених відходів збільшилася й становила 1587, 1 тис. тонн, а надалі з кожним роком зменшувалася, і 2017 року показник становив 457,7 тис. тонн. 2018 року відбулося значне збільшення утворення відходів. Рівень утилізації (переробки) відходів перебуває на дуже низькому рівні порівняно з їх утворенням. Відсоток використання був найменшим 2013 року (8,5\%), а найбільшим 2017 р. (23, 7\%).

Висновки. 3 метою вирішення санітарно-екологічних проблем, пов'язаних з неефективним поводженням з відходами, наразі доцільним $\epsilon$ будівництво сміттєпереробних комплексів. Рекомендовано проведення подальших досліджень, спрямованих на вивчення негативного впливу відходів на стан довкілля так здоров'я населення.

Ключові слова: виробничі та побутові відходи, утилізація, сміттєзвалище, полігон.

() Станкевич В.В., Брезицька Д.М., Гущук І.В., Гільман А.Ю., Кулеша Н.П.,

Сафонов Р.В., Хоронжевська І.С.. СТАТТЯ, 2020. 
до використання пестициди, кількість яких в Україні становить майже 20 тис. т.

Вкрай незадовільним та загрозливим $€$ рівень поводження 3 біологічними та медичними відходами, які становлять високу епідемічну небезпеку. Так, у Рівненській області, як і у більшості областей України в обллікарнях та інших потужних медичних закладах, відсутні печі-інсеніратори для спалювання таких медичних відходів, що створює вкрай напружену епідемічну ситуацію [7].

Таким чином, проблема екологічно безпечного поводження з виробничими та побуто-

\section{Накопичення промислових відходів I-IV класів небезпеки (станом на 01.01.2018 р.)}

\begin{tabular}{|l|c|c|}
\hline \multicolumn{1}{|c|}{ Показник } & Одиниця виміру & Кількість \\
\hline $\begin{array}{l}\text { Суб'єкти підприємницької діяльності, } \\
\text { виробнича діяльністьяких пов'язана } \\
\text { з утворенням відходів }\end{array}$ & од & 593 \\
\hline Накопичено відходів, загалом & т & 24705376 \\
\hline у тому числі: відходи I класу небезпеки & т & - \\
\hline відходи II класу небезпеки & т & 1256 \\
\hline відходи III класу небезпеки & т & 14874 \\
\hline відходи IV класу небезпеки & т & 24689246 \\
\hline
\end{tabular}

Основні показники поводження з відходами

Таблиця 2 у 2012-2017 роках (тис. т)

\begin{tabular}{|l|c|c|c|c|c|c|c|}
\hline \multicolumn{1}{|c|}{ Показники } & 2012 & 2013 & 2014 & 2015 & 2016 & 2017 & 2018 \\
\hline Утворено & 1281 & 1587,1 & 968,2 & 843,3 & 713,2 & 457,7 & 772,5 \\
\hline Отримано зі сторони & 187,3 & 212,8 & 196,3 & 240,9 & 269,2 & 211,5 & 237,8 \\
\hline $\begin{array}{l}\text { Утилізовано } \\
\text { (перероблено) }\end{array}$ & 168,3 & 57,1 & 68,4 & 94,0 & 65,2 & 23,7 & 23,2 \\
\hline Спалено & 100,8 & 78,4 & 79,3 & 81,0 & 73,9 & 84,7 & 61,7 \\
\hline Рівень використання, \% & 21 & 8,5 & 16 & 20,75 & 19,5 & 23,68 & 17,52 \\
\hline Передано на сторону & 229,8 & 306,7 & 215,3 & 201,1 & 251,4 & 72,5 & 48,3 \\
\hline
\end{tabular}

Динаміка кількості відходів, утворених у Рівненській області у 2012-2018 роках

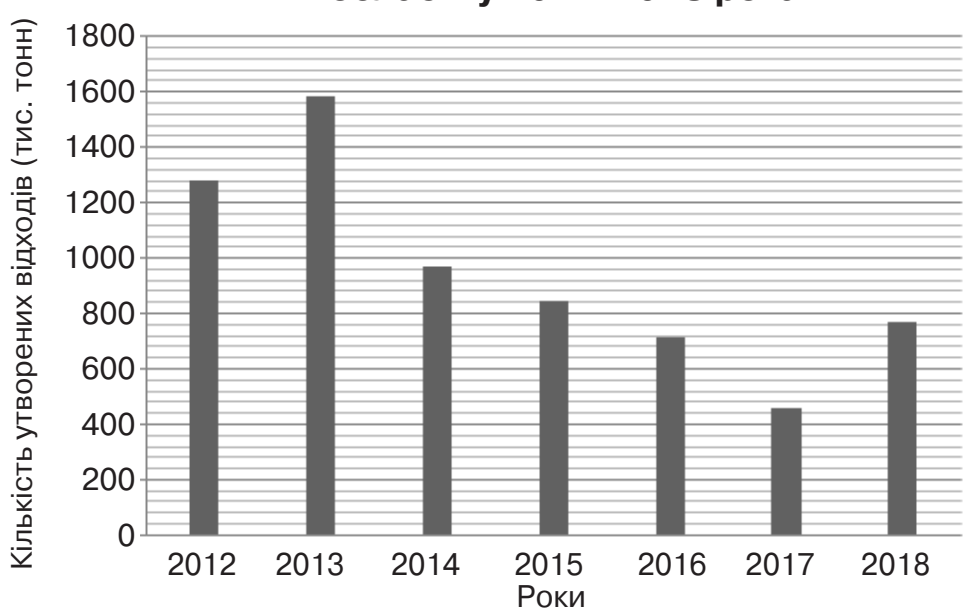

здійснювалися описовим, динамічним та порівняльним методами.

Результати досліджень. На території області нараховується понад 1000 підприємств, установ і організацій, виробнича діяльність яких пов'язана 3 утворенням промислових та побутових відходів.

Відповідно до державного статистичного спостереження ф. № 1 - відходи «Поводження з відходами» обсяг накопичення промислових відходів I-IV класів небезпеки станом на 01.01.2018 становить 24705,4 тис. т, у тому числі II-III класів небезпеки - 16,130 тис. т (табл. 1.) [8, 9].

Серед основних потужних підприємств, пов'язаних 3 утворенням та розміщенням небезпечних виробничих відходів, слід виділити ПАТ «Рівнеазот», де у відвалі площею 58,2 га - 15,4 млн. т фосфогіпс-дигідрату - відходів від виробництва фосфорної кислоти. У накопичувачі для зберігання токсичних відходів площею 2,09 га заскладовано 2,081 тис. т небезпечних відходів, переважно моноетаноламіну, який утворюється під час виробництва аміаку, у шламонакопичувачі площею 45,3 га розміщено 1,417540 млн. т шламу станції нейтралізації цеху фосфорної кислоти.

Актуальним для області $€$ накопичення заборонених і не придатних до використання хімічних засобів захисту рослин (ХЗЗР), близько 47 т. За результатами робіт районних інвентаризаційних комісій, 2017 року залишок пестицидів на території області становив 46,815 т. Лише у Володимирецькому, Гощанському, Демидівському, Костопільському та Зарічненському районах відсутні непридатні ХЗ3Р. Їхні залишки становлять 4,345 т у Березнівському районі, у Дубенському - 3,7 т, у Дубровицькому - 2,057 т, у Здолбунівському - 10,47 т, у Корецькому - 1,5 т, у Млинівському 0,3 т, в Острозькому - 1,367 т, у Радивилівському - 0,5 т, у Рівненському - 12,076 т, у Рокитнівському - 2,0 т, у Сарненському - 0,3 т, у місті Рівне - 8,2 т.

Дані щодо утворення i поводження 3 відходами у 
HYGIENIC ASSESSMENT OF THE STATE OF WASTE MANAGEMENT IN THE RIVNE REGION IN 2012-2018

1Stankevych V.V., 2 Brezytska D.M.,

2Hushchuk I.V., 2 Hilman A.Y., ${ }^{2}$ Kulesha N.P., 3Safonov R.V., 3Horonzhevska I.S.

1SI «O.M. Marzieiev Institute for Public Health, NAMN Ukraine», Kyiv

2SIC «Human Ecology and Public Health»

of the National University of Ostroh Academy Ostroh, Ukraine

${ }^{3}$ State Institution «Rivne Regional Laboratory Center of the Ministry of Health of Ukraine», Rivne, Ukraine

Objective: We carried out a hygienic assessment of the state of waste management in the Rivne region in 2012-2018.

Methods: We systematized, processed and analyzedthe research materials with the help of descriptive, dynamic and comparative methods.
Results: Analysis of the data on the amount of generated waste for 2012-2018 showed that in 2013 the amount of waste generation increased and made up 1587. 1 thousand tons, and then every year it got smaller, and in 2017 it was 457.7 thousand tons. In 2018 a significant increase in waste generation occurred. The level of utilization (processing) of waste is at a very low level with respect to its formation. The percentage of use was the smallest in $2013-8.5 \%$, and the largest in $2017-23.7 \%$.

Conclusions: In order to solve sanitary and ecological problems associated with the inefficient waste management, it is currently advisable to build garbage processing facilities. The further work is recommended to study the negative impact of waste both on the state of the environment and on the state of health of the population.

Keywords: analysis, waste, disposal, landfill, recycling.
Рівненській області за 20122018 роки представлено у таблиці 2 [8, 9].

Аналіз статистичних даних показав, що 2013 року кількість утворених відходів збільшилась і становила 1587,1 тис. т (+24\% щодо 2012 р.), а далі 3 кожним роком ставала все меншою і 2017 р. становила 457,7 тис. т, (-64\% щодо 2012 р.). 2018 року значно збільшилося утворення відходів порівняно з 2017 р. (+69\%) (рис. 1).

На об'єктах поводження 3 ТПВ від початку їх експлуатації захоронено 32,95 млн. м³ відв області одним 3 основних способів видалення твердих побутових відходів $€$ захоронення їх на сміттєзвалищах, які у переважній більшості не відповідають санітарно-екологічним вимогам [10].

Слід зазначити, що рівень утилізації (переробки) відходів в області перебуває на дуже низькому рівні порівняно 3 їх утворенням. Ймовірно, причиною $€$ те, що більшість населення проживає у сільській місцевості, де відсутні баки для сміття, а у містах, де вони навіть $€$, сміття не сортують, що $€$ обов'язковою умовою для переробки. Тому й рівень використання відходів є дуже низьким. Відсоток використання був найменшим 2013 року - лише 8,5\%, а найбільшим 2017 р. - 23,68\%. Цей показник знову почав зменшуватися 2018 року і становив $17,52 \%$ (рис. 2). ходів та їхніх компонентів. Нині
Роздільне збирання твердих побутових відходів контейнерним методом впроваджене у 56 населених пунктах області. На території Шпанівської сільської ради Рівненського району (с. Шпанів) 2013 року введено в експлуатацію завод 3 переробки твердих побутових відходів. Відсортовані відходи подрібнюються і переробляються на паливо. Обов'язково відділяється матеріал, який переробляють на вторинну сировину та продають - скло, залізо, кольорові метали. Проектна потужність означеного заводу - 120 тис. тонн на рік. Згідно з планом виробництва 50,5\% - альтернативне паливо (використовується на цементному заводі філії «Волинь-Цемент» ПАТ «Дікергофф цемент Україна» у м. Здолбунів), 9,8\% - вторинна сировина, 39,7\% - компост та тех-

\section{Динаміка рівня використання відходів у Рівненській області у 2012-2018 роках \\ Рисунок 2}

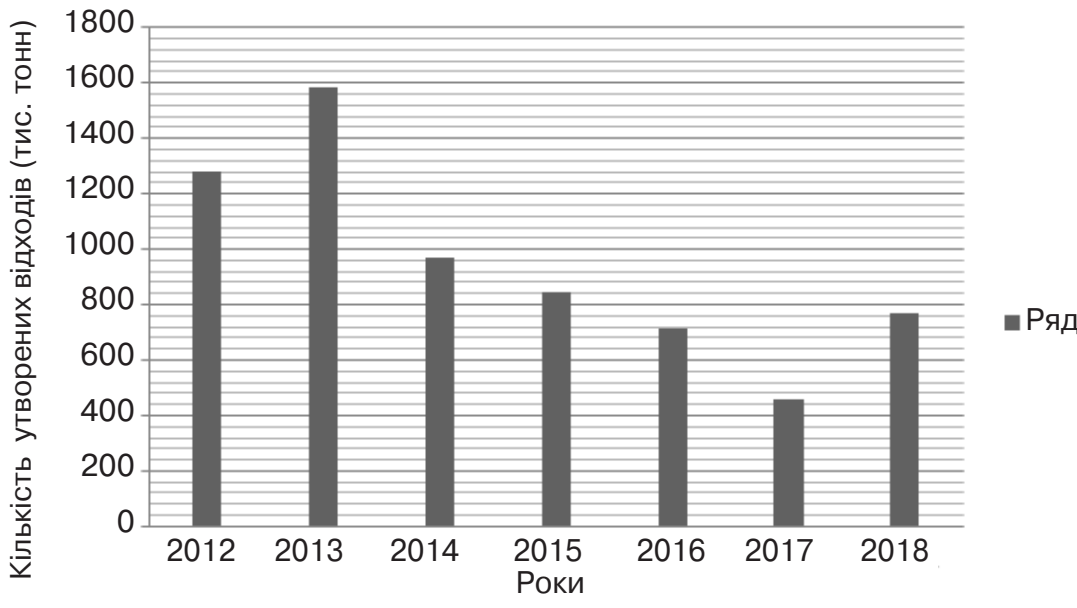
переробних комплексів. 415,47 га. 22,9 тис. $\mathrm{M}^{3}(2 \%)$. побутових відходів). нічні матеріали. Планується будівництво ще кількох сміттє-

Станом на 01.01.2019 загальна кількість полігонів та звалищ твердих побутових відходів у містах та селищах області становить 346 одиниць, загальною площею

За звітними даними, 2018 року у населених пунктах області утворилося 1130,5 тис. м $^{3}$ ТПВ, що становить 196,9 тис. т, з них захоронено на полігонах, звалищах 1107,6 тис. м³ (98\%), відправлено на заготівельні пункти вторинної сировини

Станом на 01.01.2019 з 346 полігонів і звалищ побутових відходів, внесених до реєстру місць видалення відходів у Рівненській області, діючими є 339 (4 полігони та 335 звалищ

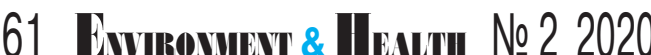


ходів, відходи не ущільнюються та не засипаються ґрунтом, частина сміттєзвалищ потребує обваловки та насадження кущів, дерев, прилегла територія - прибирання.

За даними обласного лабораторного центру, під час проведення досліджень проб ґрунту визначено, що він не відповідає санітарно-гігієнічним вимогам. Вищевказане свідчить про негативний вплив на ґрунт не лише хімічних, а й значною мірою біологічних чинників.

3 метою розв'язання ключових санітарно-гігієнічних та екологічних проблем, пов'язаних 3 неефективним поводженням з відходами, що призводить до нарощування антропогенного навантаження на довкілля, нині $€$ доцільним будівництво сміттєпереробних комплексів (СПК). СПК це високорентабельне й екологічно чисте виробництво, на якому не лише переробляється сміття (до 94\%), але й за рахунок виробництва виготовляються 3 нього матеріали, сировина, вироби.

Окрім того, необхідно проводити активну санітарно-просвітню роботу серед населення.

\section{Висновки}

1. На Рівненщині, як і загалом по Україні, забруднення навколишнього природного середовища промисловими та твердими побутовими відходами набуває все більшої гостроти. Відсутність ефективної системи поводження 3 відходами на рівні регіону зумовлює накопичення значної кількості їх у місцях видалення, що призводить до антропогенного навантаження на довкілля, забруднення його основних компонентів: ґрунту, атмосферного повітря, водних ресурсів та погіршення умов проживання населення області. Доцільне проведення подальших робіт, спрямованих на вивчення негативного впливу відходів на стан довкілля та здоров'я населення.

2. Аналіз даних щодо кількості утворених відходів за 20122018 роки показав, що 2013 року їхня кількість була найбільшою (1587,1 тис .т), а далі 3 кожним роком ставала все меншою, 2017 року показник був найменшим $(457,7$ тис. т).
При цьому переробка відходів перебуває на дуже низькому рівні порівняно з їх утворенням .

Відсоток використання був найменшим 2013 року і становив лише 8,5\%, а найбільшим 2017 p. $-23,7 \%$

3. 3 метою розв'язання санітарно-екологічних проблем, пов'язаних 3 неефективним поводженням з відходами, що призводить до нарощування антропогенного навантаження на довкілля, нині доцільним $€$ будівництво сміттєпереробних комплексів (СПК).

\section{ЛІТЕРАТУРА}

1. Eurostat. Waste statistics Statistics Explained. URL : https://ec.europa.eu/eurostat/statistics-explained/index. php?title=Waste_statistics\#Haz ardous_waste_generation

2. Директива 2008/98/€С Європейського Парламенту та Ради від 19.11.2008 «Про відходи та скасування окремих Директив». Офіційний вісник ЄC. 2008. L 312. C. 3-30.

3. Директива 1999/31/ЭС Європейського Парламенту та Ради від 26.04.1999 «Про захоронення відходів зі змінами і доповненнями, внесеними Регламентом (ЄС) 1882/2003». Офіційний вісник ЄC. 1999. L 182. C. 1-19.

4. Державна служба статистики України. Відходи. URL : http://www.ukrstat.gov.ua/oper ativ/menu/menu u/ns.htm

5. Станкевич В.В., Костенко А.І., Трахтенгерц Г.А. Досвід застосування вимог директив ЄС для визначення ступеня небезпеки промислових відходів. Довкілля та здоров'я. 2018. № 3 (88). С. 50-56.

6. Станкевич В.В., Костенко А.І., Трахтенгерц Г.Я. Впровадження гармонізованих стандартів у сфері поводження $з$ відходами. Актуальні питання гігієни та екологічної безпеки України (XII марзєєвські читання) : зб. тез доп. наук.-практ. конф. К., 2016. Вип. 16. С. 192-195.

7. Брезицька Д.М., Гущук І.В. Проблемні питання при поводженні з медичними відходами в Україні. Вісник соціальної гігієни та організації охорони здоров'я України. 2019. № 3 (81). C. 44-50.

8. Департамент екології та природних ресурсів в виявлено часті випадки хаотичного накопичення від- 
ГИГИЕНИЧЕСКАЯ ОЦЕНКА СОСТОЯНИЯ ОБРАЩЕНИЯ С ОТХОДАМИ В РОВЕНСКОЙ ОБЛАСТИ В 2012-2018 ГОДАХ

1 Станкевич В.В., 2 Брезицкая Д.М., 2Гущук И.В., 2Гильман А.Ю., 2Кулеша Н.П., ${ }^{3}$ Сафонов Р.В., ${ }^{3}$ Хоронжевская И.С. 1 ГУ «Институт общественного здоровья им. А.Н. Марзеева НАМН Украины», г. Киев 2 НИЦ «Экологии человека и охраны общественного здоровья» Национального университета «Острожская академия»,

г. Острог, Украина

зГУ «Ровенский областной лабораторный центр МЗ Украины», г. Ровно, Украина

Цель. Гигиеническая оценка состояния обращения с отходами в Ровенской области в 2012 2018 годах.

Методы. Систематизация, обработка и анализ материалов исследований осуществлялись с помощью описательного, динамического и сравнительного методов.

Результаты. Анализ данных по количеству образованных отходов за 2012-2018 годы показал, что в 2013 г. количество образованных отходов увеличилось и составило 1587, 1 тыс. тонн, а дальше с каждым годом их становилось все меньше. В 2017 году показатель составил 457,7 тыс. тонн. В 2018 г. произошло значительное увеличение образования отходов. Уровень утилизации (переработки) отходов находится на очень низком уровне по рсавнению с их образованием. Процент использования был наименьшим в 2013 году (8,5\%), а самым высоким - в $2017(23,7 \%)$

Выводы. С целью решения санитарно-экологических проблем, связанных с неэффективным обращением с отходами, в настоящее время целесообразно строительство мусороперерабатывающих комплексов. Рекомендуется проведение дальнейших работ, направленных на изучение негативного воздействия отходов на состояние окружающей среды и здоровье населения.

Ключевые слова: производственные и бытовые отходы, утилизация, свалка, полигон.
Рівненської облдержадміністрації. Доповідь про стан навколишнього природного середовища у Рівненській області у 2013 р. Рівне, 2014. C. 128-134. URL :

http://www.ecorivne.gov.ua/tm p/dopovid_2013.pdf

9. Департамент екології та природних ресурсів

Рівненської облдержадміністрації. Доповідь про стан навколишнього природного середовища у Рівненській області у 2018 р. Рівне, 2019. C. 118-124. URL:

http://www.ecorivne.gov.ua/rep ort_about_environment/

10. Лико Д.В., Гущук I.B. Проблемні питання щодо поводження з відходами та їх утилізації у Рівненській області. Екологія довкілля та безпека життєдіяльності. 2008. № 5. С. 47-49.

REFERENCES

1. Eurostat. Waste Statistics Statistics Explained. URL : https://ec.europa.eu/eurostat/statistics-explained/ index.php?title=Waste_statistics\#Hazardous_waste_generation.

2. Directive 2008/98/EC of the European Parliament and of the Council of 19.11.2008 on Waste and Repealing Certain Directives (Text with EEA relevance). Official Journal. L 312 ; 22.11.2008: 3-30

3. Council Directive 1999/31/EC of 26.04.1999 on the Landfill of Waste. Official Journal. L 182 ; 16.7.1999 :
1-19.URL : https://eurlex.europa.eu/legalcontent/EN/TXT/?uri=CELEX:01 999L0031-20180704

4. State Statistic Service of Ukraine. Vidkhody [Waste]. URL: http://www.ukrstat. gov.ua/operativ/menu/menu_ u/ns.htm (in Ukrainian).

5. Stankevych V.V., Kostenko A.I. and

Trakhtenherts H.Ya. Dosvid zastosuvannia vymoh dyrektyv YeS dlia vyznachennia stupeniu nebezpeky promyslovykh vidkhodiv [Experience in the Application of the Requirements of the EU Directives to Determine the Degree of Risk of Industrial Waste]. Dovkillia ta zdorovia (Environment \& Health). 2018 ; 3(88) : 50-56 (in Ukrainian).

6. Stankevych V.V.,

Kostenko A.I. and Trakhtenherts H.Ya. Vprovadzhennia harmonizovanykh standartiv u sferi povodzhennia z vidkhodamy [Implementation of Harmonized Standards in the Field of Waste Management]. In : Aktualni pytannia hihiieny ta ekolohichnoi bezpeky Ukrainy (dvanadtsiati marzieievski chytannia) : zb. tez dop. nauk. -prakt. konf. [Topical Issues of Hygiene and Environmental Safety of Ukraine (The Twelfth Marzieiev's Reading): Proc. Conf.]. Kyiv ; 2016 ; 16 : 192-195

(in Ukrainian).

7. Brezytska D.M. and Hushchuk I.V. Problemni pytannia pry povodzhenni z medych- nymy vidkhodamy v Ukraini [Problematic Issues in the Management of Medical Waste in Ukraine]. Visnyk sotsialnoi hihiieny ta orhanizatsii okhorony zdorovia Ukrainy. 2019 ; 3(81) : 44-50 (in Ukrainian).

8. Department of Ecology and Natural Resources of Rivne Oblast State Administration. Dopovid pro stan navkolyshnoho pryrodnoho seredovyshcha v Rivnenskii oblasti u 2013 r. [Report on the State of the Environment in Rivne Oblast in 2013]. Rivne, Ukraine ; 2014 : 128-134. URL :

http://www.ecorivne.gov.ua/tm p/dopovid_2013.pdf

(in Ukrainiān).

9. Department of Ecology and Natural Resources of Rivne Oblast State Administration. Dopovid pro stan navkolyshnoho pryrodnoho seredovyshcha $v$ Rivnenskii oblasti u 2018 r. [Report on the State of the Environment in Rivne Oblast in 2018]. Rivne, Ukraine ; 2019 : 118-124. URL :

http://www.ecorivne.gov.ua/rep ort about environment/

(in Ükrainian).

10. Lyko D.V. and

Hushchuk I.V. Problemni pytannia shchodo povodzhennia z vidkhodamy ta yikh utylizatsii v Rivnenskii oblasti [Problematic Issues of Waste Management and Utilization in Rivne Oblast]. Ekolohiia dovkillia ta bezpeka zhyttiediialnosti. 2008 ; 5 : 4749 (in Ukrainian).

Надійшла до редакції 17.01.2020

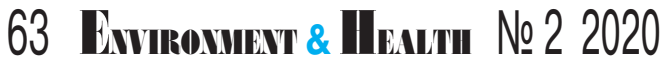

